\title{
Penerapan Fuzzy TOPSIS dalam Penentuan Lokasi Kawasan Pengembangan Rantai Pasok Bioenergi Kelapa Sawit
}

\author{
The Application of Fuzzy TOPSIS to Determine The Location for Area Development of \\ Palm Oil Based Bioenergy Supply Chain \\ Petir Papilo1*, Taufik Djatna², Yandra Arkeman², Marimin² \\ ${ }^{1}$ Program Studi Teknik Industri, Universitas Islam Negeri Sultan Syarif Kasim Riau, \\ Jl. HR Subrantas Km. 15, No. 155 Simpang Baru Panam, Pekanbaru 28293, Indonesia \\ 2Program Studi Teknologi Industri Pertanian, Institut Pertanian Bogor, \\ Kampus IPB Darmaga PO Box 220, Bogor 16002, Indonesia \\ Email: pilo1244@gmail.com
}

Submisi: 11 Februari 2016; Penerimaan: 3 November 2017

\begin{abstract}
ABSTRAK
Penelitian ini bertujuan untuk memperoleh lokasi terbaik yang menjadi target kawasan pengembangan agroindustri bioenergi dalam satu mata rantai pasokan. Melalui pendekatan sistem, dengan menggunakan metode fuzzyTOPSIS, dilakukan analisis terhadap berbagai kriteria penting diantaranya ketersediaan bahan baku, kondisi lahan dan harga, kemudahan akses transportasi, jarak lokasi dengan pusat kota, ketersediaan tenaga kerja pada lokasi sasaran, ketersediaan infrastruktur seperti air dan listrik, orientasi pemanfaatan lokasi serta multiflier effect. Berdasarakan hasil analisis yang telah dilakukan, dari lima target kawasan yang menjadi sasaran lokasi pengembangan agroindustri bioenergi di Provinsi Riau, diantaranya Kawasan Industri Kuala Enok, Kawasan Perkebunan Kelapa Sawit di Rokan Hulu, Kawasan Industri Pelintung Dumai, Kawasan Perkebunan Kelapa Sawit di Bagan Batu Rokan Hilir dan Kawasan Teknopolitan di Kabupaten Pelalawan, telah terpilih lokasi terbaik, yakni di Kawasan Industri Pelintung Dumai
\end{abstract}

Kata kunci: Bioenergi; fuzzyTOPSIS; lokasi; kelapa sawit; rantai pasok

\section{ABSTRACT}

This study aims to obtain the best location of the target area of agro-industrial development of bioenergy in the supply chain. Through a systems approach, using fuzzy TOPSIS, an analysis of various key criteria was conducted, including availability of raw materials, land conditions and prices, the ease of access to transportation, the distance to the city center, the availability of labor at the target location, availability of infrastructure - such as water and electricity, the use of the location and orientation of multiplier effect. Based on the results of the analysis that has been done, from the five areas being targeted for locations of bioenergy agro-industry development in the province of Riau, including Industrial Area Kuala Enok; Palm Oil Region in Rokan Hulu; Pelintung Dumai Industrial Area; Palm Oil Region in Bagan Batu Rokan Hilir and Teknopolitan Region in Pelalawan, the one that has been voted the best location is Pelintung Dumai Industrial Area.

Keywords: Bioenergy; fuzzy TOPSIS; location; oil palm; supply chain

\section{PENDAHULUAN}

Kelapa sawit merupakan salah satu komoditas potensial sebagai sumber penghasil bioenergi. Minyak kelapa sawit kasar yang dihasilkan merupakan bahan baku utama untuk menghasilkan bahan bakar nabati berupa biodiesel. Sedangkan limbah perkebunan kelapa sawit dalam bentuk tandan kosong, serat, cangkang serta limbah cair (POME), berpotensi untuk dimanfaatkan sebagai sumber energi listrik (Hambali dkk., 2010). Bioenergi pada umumnya tersedia dalam bentuk cair seperti biodiesel atau bioethanol, berwujud gas atau yang dikenal sebagai biogas serta berwujud padat seperti pelet, briket atau biobriket (Soerawidjaja, 2011). Pemanfaatan bioenergi sangat luas diantaranya penghasil panas (heat), sumber energi listrik (electricity) serta sebagai bahan bakar (fue) (BPPT, 2011).

Provinsi Riau merupakan wilayah penghasil kelapa sawit terbesar di Indonesia. Kondisi lahan dan 
lingkungan yang mendukung, menyebabkan kelapa sawit dapat tumbuh dengan baik di seluruh wilayah kabupaten di Provinsi Riau. Hingga tahun 2012, luas wilayah perkebunan yang ada di Provinsi Riau mencapai 3.423.560 ha yang terdiri dari perkebunan kelapa sawit milik rakyat dan swasta. Dari total luas tanam yang ada, telah dihasilkan sebanyak 8.128.472,0 ton tandan buah segar kelapa sawit (Dinas Perkebunan Provinsi Riau, 2012). Dari total potensi keseluruhan sumber daya yang telah dihasilkan selama tahun 2012, secara teoritis berpotensi menghasilkan energi biomassa sebesar 111.567.320,34 giga Joule. Dari keseluruhan potensi energi tersebut, 56,89\% potensi energi biomassa yang dapat dihasilkan dari pekebunan kelapa sawit. Adapun lima wilayah potensial komoditas kelapa sawit di Provinsi Riau antara lain: Kabupaten Kampar, Rokan Hulu, Rokan Hilir, Siak dan Pelalawan (Enreach, 2013).

Pengembangan kawasan agroindustri yang dapat menunjang sistem rantai pasok bioenergi, bagaimanapun akan selalu terkait dengan masalah keputusan pemilihan lokasi dan alokasi. Lokasi dalam hal ini merujuk pada dimana aktivitas produksi tersebut berada di permukaan bumi atau letak geografisnya, sementara alokasi merujuk pada seberapa baik industri tersebut dapat memenuhi permintaan yang ada dari posisinya tersebut (Chapman, 2009).

Christou (2012) menyatakan bahwa aspek lokasi memfokuskan kepada pemilihan lokasi optimal dari berbagai alternatif lokasi yang berguna untuk menempatkan berbagai fasilitas yang ada secara efisien. Dalam konteks manajemen operasi tradisional, sejumlah metode telah dikembangkan untuk memandu dalam pengambilan keputusan pemilihan lokasi optimal.

Salah satu metode pengambilan keputusan multikriteria adalah dengan metode Fuzzy TOPSIS. TOPSIS merupakan singkatan dari Technique for Order Performance by Similarity to Ideal Solution, yang pertama dikenalkan oleh Hwang dan Yoon (1995). Metode Fuzzy TOPSIS merupakan suatu metode yang dapat membantu dalam mengevaluasi berbagai alternatif dari berbagai kriteria yang diperhatikan, termasuk dalam penentuan suatu lokasi agroindustri. Di dalam pendekatan Fuzzy TOPSIS, pemilihan alternatif dilakukan berdasarkan nilai kedekatan dengan nilai solusi ideal positif (FPIS) dan atau jauh dari nilai solusi ideal negatif (FNIS). Langkahlangkah penerapan FuzzyTOPSIS telah banyak digunakan dalam pengambilan keputusan diantaranya Rouyendegh dan Saputro (2014); Wardani dkk. (2012); Ningrum dkk. (2012), dan Uyun dan Riadi (2011).

Sama halnya dengan agroindustri lainnya, pemilihan lokasi agroindustri bioenergi tidak terlepas dari proses penilaian terhadap berbagai kriteria penting yang perlu diperhatikan, diantaranya adalah faktor ketersediaan bahan baku, kondisi dan harga lahan, kedekatan dengan pasar dan sebagainya. Oleh karenanya, untuk mendapatkan suatu lokasi terbaik dari berbagai alternatif yang ada, diperlukan suatu pendekatan yang dapat dijadikan sebagai landasan pengambilan keputusan.
Adapun tujuan yang ingin dicapai dari penelitian ini antara lain: 1) Melakukan perancangan model penentuan lokasi kawasan pengembangan rantai pasok agroindustri bioenergi berbasis kelapa sawit; 2) Melakukan evaluasi terhadap kriteria-kriteria penting yang perlu diperhatikan dalam pemilihan lokasi suatu agroindustri bioenergi; dan 3) Memilih alternatif lokasi dari berberapa wilayah potensial yang menjadi target kawasan pengembangan agroindustri bioenergi di Provinsi Riau.

\section{METODE PENELITIAN}

\section{Tahapan Input Data}

Data input dalam penelitian ini diperoleh berdasarkan pendapat pakar. Data pendapat pakar diubah ke dalam bentuk bilangan fuzzy. Adapun tahapan input data model dapat diuraikan menjadi 2 tahap antara lain: 1) Melakukan jejak pendapat pakar melalui penyebaran kuisioner berkait penilaian terhadap kriteria-kriteria pemilihan lokasi serta alternatif lokasi yang menjadi sasaran kawasan pengembangan agroindustri bioenergi. Penilaian pakar disusun dalam bentuk matriks perbandingan antar kriteria; 2) Melakukan perangkingan terhadap pendapat pakar ke dalam bilangan fuzzy, Dk; $(\mathrm{k}=1,2,3, \ldots . \mathrm{K})$ yang direpresentasikan sebagai bilangan segitiga fuzzy ${ }^{\sim} \mathrm{Rk} ;(\mathrm{k}=1,2,3, \ldots, \mathrm{K})$ dengan fungsi keanggotaan $\mu \sim \mathrm{R}(\mathrm{x})$.

Fungsi keanggotaan fuzzy merupakan kurva yang menunjukkan pemetaan nilai input ke dalam nilai-nilai keanggotaan dengan interval antara 0 dan 1 (Kusumadewi, 2003). Untuk memetakan nilai-nilai keanggotaan tersebut dapat dilakukan dengan menggunakan suatu fungsi. Dalam penelitian ini, fungsi keanggotaan fuzzy yang digunakan adalah triangular fuzzy number (TFN). Secara lengkap fungsi keanggotaan TFN dirumuskan dalam Persamaan 1.

$$
\mu(\mathrm{x})=\left\{\begin{array}{cc}
0 ; & \mathrm{x} \leq \mathrm{l} \text { atau } \mathrm{x} \geq \mathrm{u} \\
(\mathrm{x}-\mathrm{l}) /(\mathrm{m}-\mathrm{l}) ; & \mathrm{l} \leq \mathrm{x} \leq \mathrm{m} \\
(\mathrm{u}-\mathrm{x}) /(\mathrm{u}-\mathrm{b}) ; & \mathrm{m} \leq \mathrm{x} \leq \mathrm{u}
\end{array}\right.
$$

Tabel 1 menyajikan fungsi keanggotaan TFN dan resiprokalnya.

Tabel 1. Skala perbandingan kriteria fuzzy TOPSIS

\begin{tabular}{clcc}
$\begin{array}{c}\text { Bilangan } \\
\text { Fuzzy }\end{array}$ & \multicolumn{1}{c}{ Keterangan } & $\begin{array}{c}\text { Keanggotaan } \\
\text { TFN }\end{array}$ & $\begin{array}{c}\text { Resiprokal } \\
\text { TFN }\end{array}$ \\
\hline$\sim 1$ & A Sama penting dengan B & $1,1,3$ & $(1 / 3,1,1)$ \\
$\sim 3$ & A Sedikit lebih penting dari B & $1,3,5$ & $(1 / 5,1 / 3,1)$ \\
$\sim 5$ & A Jelas lebih penting dari B & $3,5,7$ & $(1 / 7,1 / 5,1 / 3)$ \\
$\sim 7$ & A Sangat jelas lebih penting & $5,7,9$ & $(1 / 9,1 / 7,1 / 5)$ \\
& dari B & $7,9,9$ & $(1 / 9,1 / 9,1 / 7)$ \\
$\sim 9$ & A Mutlak lebih penting dari B & &
\end{tabular}

\section{Tahapan Analisis Data}

Data yang telah diubah ke dalam bentuk bilangan fuzzy diolah untuk keperluan evaluasi. Formulasi dari setiap tahapan analisis data meliputi 7 hal, yakni: 
Pertama, menentukan agregasi bobot dari setiap kriteria $\left(\tilde{x}_{i j}\right)$ untuk mendapatkan agregat bobot fuzzy $\left(\widetilde{w}_{j}\right)$ pada kriteria $C_{j}$ dan tentukan nilai agregat fuzzy dari alternatif $A i$ pada setiap kriteria $C$ j. Agregasi bobot setiap kriteria diperoleh dengan Persamaan 2.

$\tilde{\mathrm{X}}_{\mathrm{ij}}=\frac{1}{\mathrm{k}}\left[\tilde{\mathrm{x}}_{\mathrm{ij}}^{1}+\tilde{\mathrm{X}}_{\mathrm{ij}}^{2}+\ldots .+\tilde{\mathrm{x}}_{\mathrm{ij}}^{\mathrm{k}}\right]$,

dengan $\mathrm{i}=1,2, \ldots, \mathrm{m}$; dan $\mathrm{j}=1,2, \ldots, \mathrm{n}$

Sedangkan agregasi bobot fuzzy diperoleh dengan menggunakan Persamaan 3.

$\widetilde{\mathrm{w}}_{\mathrm{j}}=\frac{1}{\mathrm{k}}\left[\widetilde{\mathrm{w}}_{\mathrm{j}}^{1}+\widetilde{\mathrm{w}}_{\mathrm{j}}^{2}+\ldots .+\mathrm{w}_{\mathrm{j}}^{\mathrm{k}}\right]$,

dengan $\mathrm{j}=1,2, \ldots, \mathrm{n}$

Kedua, membangun matriks keputusan fuzzy yang dapat diperoleh dengan Persamaan 4.

$$
\widetilde{\mathrm{D}}=\begin{gathered}
\mathrm{A}_{1} \\
\mathrm{~A}_{2} \\
\mathrm{~A}_{\mathrm{m}}
\end{gathered}\left[\begin{array}{lllll}
\tilde{\mathrm{x}}_{11} & \tilde{\mathrm{x}}_{12} & C_{2} & \ldots & \tilde{\mathrm{x}}_{1 \mathrm{n}} \\
\tilde{\mathrm{x}}_{21} & \tilde{\mathrm{x}}_{22} & \ldots & \tilde{\mathrm{x}}_{2 \mathrm{n}} \\
\tilde{\mathrm{x}}_{\mathrm{m} 1} & \tilde{\mathrm{x}}_{\mathrm{m} 2} & \ldots & \tilde{\mathrm{x}}_{\mathrm{mn}}
\end{array}\right],
$$

$\widetilde{\mathrm{W}}=\left[\widetilde{\mathrm{w}}_{1}, \widetilde{\mathrm{w}}_{2} \ldots \widetilde{\mathrm{w}}_{\mathrm{n}}\right]$,

dengan $i=1,2, \ldots, m$; dan $j=1,2, \ldots, n$

Ketiga, melakukan normalisasi matrik keputusan sesuai Persamaan 5. Untuk menghitung $\left[\tilde{r}_{i j}\right]_{m x n}$ dapat dilakukan sesuai Persamaan 6.

$$
\begin{aligned}
& \widetilde{R}=\left[\tilde{r}_{i j}\right]_{m \times n} \prime \\
& \text { dengan } i=1,2, \ldots, m ; \text { dan } j=1,2, \ldots, n \\
& \tilde{r}_{i j}=\left(\frac{l_{i j}}{U_{j}^{*}}, \frac{m_{i j}}{U_{j}^{*}}, \frac{u_{i j}}{U_{j}^{*}},\right), \operatorname{dimana} U_{j}^{*}=\max u_{i j}, \\
& \text { dengan } i=1,2, \ldots, m ; \text { dan } j=1,2, \ldots, n
\end{aligned}
$$

Keempat, melakukan normalisasi bobot dari matrik keputusan fuzzy. Untuk kepentingan berbeda dari setiap kriteria. Matriks normalisasi keputusan fuzzy dapat diperoleh dengan Persamaan 7 dan 8.

$$
\begin{aligned}
& \widetilde{V}=\left[\widetilde{v}_{i j}\right]_{m \times n}, \\
& \text { dengan, } i=1,2, \ldots, m ; \text { dan } j=1,2, \ldots, n \\
& \tilde{v}_{i j}=\tilde{r}_{i j} \otimes \widetilde{w}_{i j} \\
& \text { dengan, } i=1,2, \ldots, m ; \text { dan } j=1,2, \ldots, n
\end{aligned}
$$$$
\text { dimana: }
$$

Kelima, menentukan solusi positif yang ideal Fuzzy (FPIS) $\mathrm{S}^{+}$dan solusi negatif-ideal Fuzzy (FNIS) $\mathrm{S}^{-}$. Perhitungan dapat diperoleh seperti pada Persamaan 9 dan 10.

$$
\begin{aligned}
& \mathrm{S}^{+}=\left(\widetilde{\mathrm{V}}_{1}^{+}, \tilde{\mathrm{v}}_{2}^{+}, \ldots ., \widetilde{\mathrm{v}}_{\mathrm{n}}^{+}\right) \\
& \mathrm{S}^{-}=\left(\tilde{\mathrm{V}}_{1}^{-}, \tilde{\mathrm{V}}_{2}^{-}, \ldots, \widetilde{\mathrm{V}}_{\mathrm{n}}^{-}\right)
\end{aligned}
$$

dimana: $\tilde{v}_{j}^{+}=\max \left\{v_{i j 3}\right\}$ dan $\tilde{v}_{j}^{-}=\min \left\{v_{i j 1}\right\}$ dengan $\tilde{\mathrm{v}}_{\mathrm{j}}$ merupakan bobot normalisasi TFN.

Keenam, menghitung jarak nilai antara setiap nilai alternatif dengan nilai FPIS dan FNIS dengan Persamaan 11 sampai 13 .

$$
\begin{aligned}
& d\left(A_{1}, A_{2}\right)=\sqrt{\frac{1}{3}\left[\left(l_{1}-I_{2}\right)^{2}\right.}+\left(m_{1}-m l_{2}\right)^{2}+\left(u-u_{2}\right)^{2}(11) \\
& d_{1}^{+}=\sum_{j=1}^{n} d\left(\tilde{v}_{i j}, \tilde{v}_{j}^{+}\right), \\
& \text {dengan } i=1,2, \ldots ., m ; \text { dan } j=1,2 \ldots ., n \\
& d_{1}^{-}=\sum_{j=1}^{n} d\left(\tilde{v}_{i j}, \tilde{v}_{j}^{-}\right), \\
& \text {dengan } i=1,2, \ldots . ., m ; \text { dan } j=1,2 \ldots ., n
\end{aligned}
$$

Ketujuh, menghitung nilai koefisien kedekatan antar jarak (Cci) dan rangking sesuai dengan nilai koefisien yang diperoleh dengan Persamaan 14.

$$
\begin{gathered}
\mathrm{CC}_{\mathrm{i}}=\frac{\mathrm{d}_{\mathrm{i}}^{-}}{\mathrm{d}_{\mathrm{i}}^{+}+\mathrm{d}_{\mathrm{i}}^{-}}, \\
\text {dengan } \mathrm{i}=1,2, \ldots ., \mathrm{m}
\end{gathered}
$$

\section{Output Analisis}

Adapun output analisis berupa nilai preferensi antar alternatif yang diperbandingkan. Nilai preferensi ditentukan berdasarkan nilai jarak antar nilai solusi ideal positif dan solusi ideal negatif, dimana alternatif terbaik dengan tingkat preferensi yang paling disukai adalah alternatif yang memiliki nilai jarak terbesar.

\section{Evaluasi Pemilihan Lokasi}

Pengembangan suatu kawasan industri tidak terlepas dari proses pengambilan keputusan pemilihan lokasi. Hal ini dikarenakan banyaknya faktor ataupun kriteria yang mempengaruhi di wilayah lokasi. Analisis multikriteria melalui pendekatan Fuzzy TOPSIS diharapkan mampu memberikan hasil keputusan lokasi terbaik dalam upaya pengembangan bioenergi berbasis kelapa sawit di Provinsi Riau.

Kementrian Perindustrian dan Perdagangan, melalui peraturan menteri No. 35 Tahun 2010 tentang petunjuk teknis pengembangan kawasan industri, telah menetapkan 14 kriteria yang harus dipertimbangkan. Pada peraturan tersebut juga telah ditetapkan ambang batas dari masing-masing kriteria yang perlu dipertimbangkan oleh berbagai pihak yang akan melaksanakan pemilihan dan penentuan lokasi suatu kawasan industri.

Adapun 14 kriteria penentuan lokasi kawasan agroindustri bioenergi kelapa sawit tersebut terangkum dalam Tabel 2. 
Tabel 2. Kriteria-kriteria pemilihan lokasi kawasan industry

\begin{tabular}{|c|c|c|}
\hline No & $\begin{array}{l}\text { Kriteria pemilihan } \\
\text { lokasi }\end{array}$ & Faktor pertimbangan \\
\hline 1 & Jarak ke pusat kota & Minimal $10 \mathrm{~km}$ \\
\hline 2 & $\begin{array}{l}\text { Jarak terhadap } \\
\text { pemukiman }\end{array}$ & Minimal 2 km \\
\hline 3 & Kondisi jalan & Arteri primer \\
\hline 4 & $\begin{array}{l}\text { Sistem jaringan yang } \\
\text { melayani }\end{array}$ & $\begin{array}{l}\text { Tersedianya jaringan listrik } \\
\text { dan telekomunikasi }\end{array}$ \\
\hline 5 & Prasarana angkutan & $\begin{array}{l}\text { Tersedianya pelabuhan laut } \\
\text { sebagai outlet (eksport/ } \\
\text { import) }\end{array}$ \\
\hline 6 & $\begin{array}{l}\text { Topografi/kemiringan } \\
\text { tanah }\end{array}$ & Maksimal $15^{\circ}$ \\
\hline 7 & $\begin{array}{l}\text { Jarak terhadap } \\
\text { sungai }\end{array}$ & $\begin{array}{l}\text { Maksimal } 5 \mathrm{~km} \text { dan terlayani } \\
\text { sungai tipe C dan D atau } \\
\text { kelas III dan IV }\end{array}$ \\
\hline 8 & Daya dukung lahan & $\begin{array}{l}\text { Sigma tanah, } \delta: 0,7-1,0 \\
\mathrm{~kg} / \mathrm{cm}^{2}\end{array}$ \\
\hline 9 & Kesuburan tanah & $\begin{array}{l}\text { Relatif tidak subur (non } \\
\text { irigasi teknis) }\end{array}$ \\
\hline 10 & Peruntukan lahan & $\begin{array}{l}\text { Non pertanian, non } \\
\text { pemukiman dan non } \\
\text { konservasi }\end{array}$ \\
\hline 11 & Ketersediaan lahan & Minimal 50 ha \\
\hline 12 & Harga lahan & $\begin{array}{l}\text { Relatif (bukan merupakan } \\
\text { lahan dengan harga yang } \\
\text { tinggi di daerah tersebut) }\end{array}$ \\
\hline 13 & Orientasi lokasi & $\begin{array}{l}\text { Aksesibilitas tinggi, dekat } \\
\text { dengan potensi tenaga kerja }\end{array}$ \\
\hline \multirow[t]{3}{*}{14} & Multiplier effects & $\begin{array}{l}\text { a) Bangkitan lalu lintas = } \\
5,5 \mathrm{smp} / \mathrm{ha} / \text { hari } \\
\text { b) Kebutuhan lahan industri } \\
\text { dan multipliernya = } 2 \times \\
\text { luas perencanaan } \\
\text { kawasan }\end{array}$ \\
\hline & & $\begin{array}{l}\text { c) Kebutuhan rumah }(1,5 \\
\text { TK } \sim 1 \mathrm{KK})\end{array}$ \\
\hline & & $\begin{array}{l}\text { d) Kebutuhan fasum dan } \\
\text { fasos }\end{array}$ \\
\hline
\end{tabular}

(Sumber: Kementerian Perindustrian dan Perdagangan, 2010)

\section{Kriteria Pemilihan Lokasi Agroindustri Bioenergi}

Dalam penelitian ini, 9 kriteria yang telah ditetapkan Kementrian Perindustrian dan Perdagangan ini menjadi acuan dalam pemilihan lokasi kawasan agorindustri bioenergi berbasis kelapa sawit. Ke-9 kriteria yang digunakan dalam kajian ini dianggap sangat mendasar dan merupakan faktor penting yang perlu dipertimbangkan dalam menentukan lokasi suatu kawasan seperti halnya kawasan agrindustri bioenergi kelapa sawit. Selain itu untuk keperluan penilaian, parameter dari kriteria-kriteria tersebut secara kualitatif maupun secara kuantitatif lebih terukur. Adapun 9 kriteria yang diperhatikan terangkum dalam Tabel 3.
Tabel 3. Kriteria-kriteria pemilikan lokasi

\begin{tabular}{ll}
\hline Kode & \multicolumn{1}{c}{ Kriteria } \\
\hline KKL & Ketersediaan dan kondisi lahan \\
HT & Harga tanah \\
KSBB & Kedekatan dengan sumber bahan \\
AST & baku \\
KAL & Akses sarana transportasi \\
JPK & Ketersediaan air dan listrik \\
KTK & Jarak ke pusat kota \\
OL & Ketersediaan tenaga kerja \\
ME & Orientasi lokasi \\
& Multiflier effect \\
\hline
\end{tabular}

\section{Alternatif Keputusan}

Alternatif keputusan adalah beberapa kawasan yang menjadi sasaran pengembangan agroindustri bioenergi yang keseluruhannya berada di wilayah Provinsi Riau. Dalam kajian ini, terdapat lima target wilayah yang akan dipilih sebagai kawasan pengembangan agroindustri seperti disajikan pada Tabel 4.

Alasan pemilihan lokasi-lokasi tersebut antara lain dikarenakan faktor-faktor seperti: 1) ketersediaan sumber bahan baku bioenergi dalam hal ini yang bersumber dari perkebunan kelapa sawit lebih tinggi dibandingkan wilayah lainnya, 2) faktor akses transportasi dan distribusi yang dianggap lebih baik dibandingkan lokasi lainnya, 3) faktor alokasi lokasi yang memang diperuntukkan sebagai target kawasan industri di Provinsi Riau. Adapun hierarki pengambilan keputusan dapat disajikan pada Gambar 2.

Tabel 4. Alternatif lokasi

\begin{tabular}{cl}
\hline Kode & \multicolumn{1}{c}{ Alternatif } \\
\hline A1 & Kuala Enok di Indragiri Hilir \\
A2 & Kawasan perkebunan kelapa sawit Tandun Rokan \\
& Hulu \\
A3 & Kawasan industri Pelintung Dumai \\
A4 & Kawasan perkebunan kelapa sawit Rokan Hilir \\
A5 & Kawasan teknopolitan Pelalawan \\
\hline
\end{tabular}

\section{Skala Penilaian}

Skala penilaian merupakan nilai yang menunjukkan tingkat kepentingan suatu kriteria dibandingkan dengan kriteria lainnya. Skala penilaian berada diantara 1 hingga 9, dimana semakin tinggi nilai yang diberikan, maka semakin penting suatu kriteria tersebut untuk dipertimbangkan. Skala penilaian perbandingan antar kriteria dapat disajikan pada Tabel 5.

Tabel 5. Skala penilaian matrik perbandingan kriteria

\begin{tabular}{cl}
\hline Skala & \multicolumn{1}{c}{ Keterangan } \\
\hline 1 & A Sama penting dengan B \\
3 & A Sedikit lebih penting dari B \\
5 & A Jelas lebih penting dari B \\
7 & A Sangat jelas lebih penting dari B \\
9 & A Mutlak lebih penting dari B \\
\hline
\end{tabular}


Secara hierarki, proses pengambilan keputusan penentuan lokasi kawasan pengembangan rantai pasok agroindustri kelapa dapat dijabarkan melalui Gambar 2.

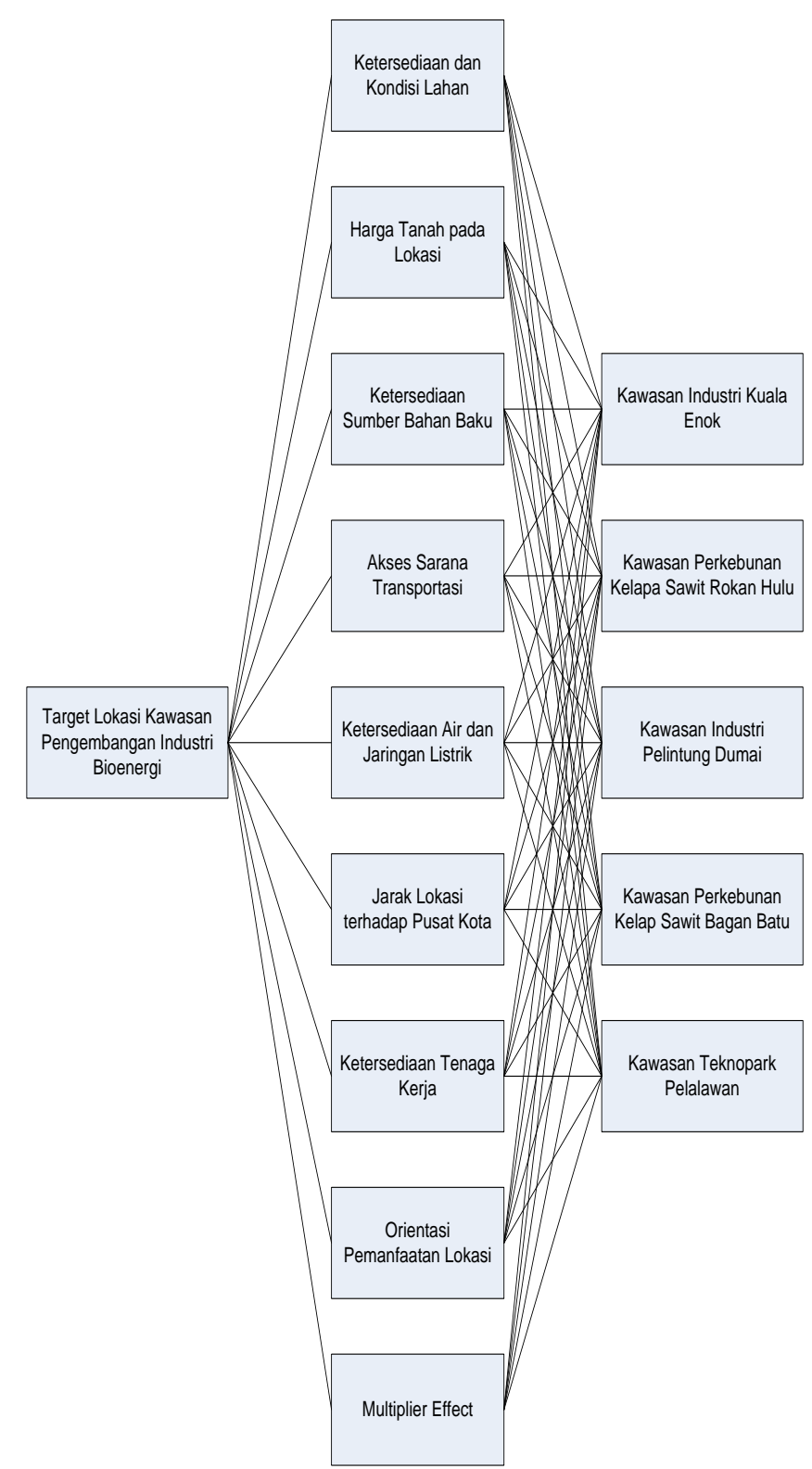

Gambar 2. Hierarki keputusan

Gambar 2 memperlihatkan hubungan keterkaitan antara kriteria-kriteria yang dipertimbang dengan alternatif-alternatif lokasi yang menjadi target kawasan pengembangan agroindustri bioenergi. Proses pengambilan keputusan sangat bergantung kepada bobot penilaian yang diberikan oleh para pakar, baik terhadap kriteria-kriteria yang dipertimbangkan maupun terhadap alternatif lokasi yang akan dipilih.

\section{Proses Pengambilan Keputusan}

Setelah melakukan perancangan hierarki keputusan, tahap selanjutnya adalah menentukan alternatif lokasi terbaik berdasarkan kondisi tiap kriteria yang terdapat pada masing-masing lokasi. Pada konsep fuzzy, penilaian diberikan dalam bentuk skala TFN yang membagi tiga rentang nilai dalam satu skala penilaian. Secara linguistik penilaian lokasi berada diantara Very Poor hingga Very Good. Skala penilaian lokasi berdasarkan kriteria ada dan preferensi pakar, dapat disajikan pada Tabel 6.

Tabel 6. Skala perbandingan alternatif fuzzy TOPSIS

\begin{tabular}{llc}
\hline Skala & & Linguistik TFN \\
\hline Very poor & (VP) & $0,0,1$ \\
Poor & (P) & $0,1,3$ \\
Med poor & (MP) & $1,3,5$ \\
Fair & (F) & $3,5,7$ \\
Med good & (MG) & $5,7,9$ \\
Good & (G) & $7,9,9$ \\
Very good & (VG) & $9,9,10$ \\
\hline
\end{tabular}

\section{HASIL DAN PEMBAHASAN}

Dalam kajian ini, mekanisme pengambilan keputusan dilakukan melalui penilaian terhadap 5 alternatif lokasi yang akan dijadikan sebagai target kawasan pengembangan industri bioenergi kelapa sawit, dimana keseluruhan lokasi berada di wilayah Provinsi Riau. Penentuan lokasi dilakukan berdasarkan atas penilaian subjektif para pakar sesuai dengan pengetahuan yang dimiliki terhadap kondisi setiap lokasi menurut 9 kriteria yang diperhatikan.

Penentuan keputusan dilakukan mengikut kaedah Fuzzy TOPSIS dengan menguraikan proses analisis ke dalam 9 tahap analisis. Hasil setiap tahapan memiliki keterkaitan satu dengan lainnya. Keputusan terbaik ditentukan berdasarkan nilai koefisien kedekatan tertinggi dari setiap alternatif yang diperbandingkan. Secara berurutan tahapan dan hasil analisis penentuan lokasi kawasan pengembangan bioenergi dengan menggunakan Metode Fuzzy TOPSIS dapat diuraikan dalam 9 tahap.

\section{Tahap 1}

Pengumpulan data input melalui penyebaran kuisioner dan disusun ke dalam matriks perbandingan. Hasil jejak pendapat pakar dalam bentuk matriks perbandingan dapat disajikan pada Tabel 7.

\section{Tahap 2}

Pemeringkatan linguistik kedalam batasan nilai TFN. Berdasarkan data penilaian pakar terhadap kriteria penentuan lokasi, maka dapat dijabarkan kedalam nilai batas bawah (low), tengah (medium) dan batas atas (upper) seperti terangkum pada Tabel 8.

\section{Tahap 3}

Mengagregasi nilai TFN kedalam bobot kepentingan dan normalisasi bobot kepentingan dari masing-masing kriteria sehingga diperoleh nilai-nilai batas atas, tengah dan bawah masing-masing bobot seperti diuraikan pada Tabel 9. 
Tabel 7. Nilai fuzzy penilaian pakar pada kriteria penentuan lokasi

\begin{tabular}{lccccccccc}
\hline Kriteria & KKL & HT & KSBB & AST & KAL & JPK & KTK & OL & ME \\
\hline KKL & 1 & $\sim 1$ & $\sim 1$ & $\sim 3$ & $\sim 3$ & $\sim 5$ & $\sim 7$ & $\sim 9$ & $\sim 9$ \\
HT & $\sim 1$ & 1 & $\sim 1$ & $\sim 3$ & $\sim 5$ & $\sim 5$ & $\sim 7$ & $\sim 9$ & $\sim 9$ \\
KSBB & $\sim 1$ & $\sim 1$ & 1 & $\sim 1$ & $\sim 3$ & $\sim 5$ & $\sim 5$ & $\sim 7$ & $\sim 7$ \\
AST & $\sim 1 / 3$ & $\sim 1 / 3$ & $\sim 1$ & 1 & $\sim 1$ & $\sim 3$ & $\sim 3$ & $\sim 5$ & $\sim 5$ \\
KAL & $\sim 1 / 3$ & $\sim 1 / 5$ & $\sim 1 / 3$ & $\sim 1$ & 1 & $\sim 1$ & $\sim 1$ & $\sim 3$ & $\sim 3$ \\
JPK & $\sim 1 / 5$ & $\sim 1 / 5$ & $\sim 1 / 5$ & $\sim 1 / 3$ & $\sim 1$ & 1 & $\sim 1$ & $\sim 1$ & $\sim 3$ \\
KTK & $\sim 1 / 7$ & $\sim 1 / 7$ & $\sim 1 / 5$ & $\sim 1 / 3$ & $\sim 1$ & $\sim 1$ & 1 & $\sim 1$ & $\sim 1$ \\
OL & $\sim 1 / 9$ & $\sim 1 / 9$ & $\sim 1 / 7$ & $\sim 1 / 5$ & $\sim 1 / 3$ & $\sim 1$ & $\sim 1$ & 1 & $\sim 1$ \\
ME & $\sim 1 / 9$ & $\sim 1 / 9$ & $\sim 1 / 7$ & $\sim 1 / 5$ & $\sim 1 / 3$ & $\sim 1 / 3$ & $\sim 1$ & $\sim 1$ & 1 \\
\hline
\end{tabular}

Tabel 8. Nilai TFN penilaian pakar pada kriteria penentuan lokasi

\begin{tabular}{|c|c|c|c|c|c|c|c|c|c|}
\hline Kriteria & $\mathrm{KKL}$ & HT & KSBB & AST & KAL & JPK & KTK & $\mathrm{OL}$ & ME \\
\hline KKL & $1,1,1$ & $1,1,3$ & $1,1,3$ & $1,3,5$ & $1,3,5$ & $3,5,7$ & $5,7,9$ & $7,9,9$ & $7,9,9$ \\
\hline HT & $0,33,1,1$ & $1,1,1$ & $1,1,3$ & $1,3,5$ & $3,5,7$ & $3,5,7$ & $5,7,9$ & $7,9,9$ & $7,9,9$ \\
\hline KSBB & $0,33,1,1$ & $0,33,1,1$ & $1,1,1$ & $1,1,3$ & $1,3,5$ & $3,5,7$ & $3,5,7$ & $5,7,9$ & $5,7,9$ \\
\hline AST & $0,2,0,33,1$ & $0,2,0,33,1$ & $0,33,1,1$ & $1,1,1$ & $1,1,3$ & $1,3,5$ & $1,3,5$ & $3,5,7$ & $3,5,7$ \\
\hline KAL & $0,2,0,33,1$ & $0,14,0,2,0,33$ & $0,2,0,33,1$ & $0,33,1,1$ & $1,1,1$ & $1,1,3$ & $1,1,3$ & $1,3,5$ & $1,3,5$ \\
\hline JPK & $0,14,0,2,0,33$ & $0,14,0,2,0,33$ & $0,14,0,2,0,33$ & $0,2,0,33,1$ & $0,33,1,1$ & $1,1,1$ & $1,1,3$ & $1,1,3$ & $1,3,5$ \\
\hline KTK & $0,11,0,14,0,2$ & $0,11,0,14,0,2$ & $0,14,0,2,0,33$ & $0,2,0,33,1$ & $0,33,1,1$ & $0,33,1,1$ & $1,1,1$ & $1,1,3$ & $1,1,3$ \\
\hline $\mathrm{OL}$ & $0,11,0,11,0,14$ & $0,11,0,11,0,14$ & $0,11,0,14,0,2$ & $0,14,0,2,0,33$ & $0,2,0,33,1$ & $0,33,1,1$ & $0,33,1,1$ & $1,1,1$ & $1,1,3$ \\
\hline ME & $0,11,0,11,0,14$ & $0,11,0,11,0,14$ & $0,11,0,14,0,2$ & $0,14,0,2,0,33$ & $0,2,0,33,1$ & $0,2,0,33,1$ & $0,33,1,1$ & $0,33,1,1$ & $1,1,1$ \\
\hline
\end{tabular}

Tabel 9. Nilai agregasi bobot dan normalisasi

\begin{tabular}{lll}
\hline \multicolumn{1}{c}{ Kriteria } & Nilai kepentingan & Normalisasi \\
\hline Ketersediaan dan kondisi lahan (KKL) & $(1,44,1,75,2,15)$ & $(0,12,0,18,0,27)$ \\
Harga tanah (HT) & $(1,44,1,80,2,07)$ & $(0,12,0,18,0,26)$ \\
Kedekatan dengan sumber bahan baku (KSBB) & $(1,27,1,72,1,92)$ & $(0,10,0,17,0,24)$ \\
Akses sarana transportasi (AST) & $(0,89,1,19,1,57)$ & $(0,07,0,12,0,20)$ \\
Ketersediaan air dan listrik (KAL) & $(0,71,0,91,1,27)$ & $(0,06,0,09,0,16)$ \\
Jarak ke pusat kota(JPK) & $(0,62,0,77,1,03)$ & $(0,05,0,08,0,13)$ \\
Ketersediaan tenaga kerja (KTK) & $(0,57,0,68,0,86)$ & $(0,05,0,07,0,11)$ \\
Orientasi lokasi (OL) & $(0,51,0,60,0,72)$ & $(0,04,0,06,0,09)$ \\
Multiflier effect (ME) & $(0,46,0,56,0,68)$ & $(0,04,0,06,0,09)$ \\
\hline Jumlah & $(7,90,9,97,12,26)$ & \\
\hline
\end{tabular}

Tabel 10. Matriks penilaian pakar terhadap alternatif dalam skala TFN

\begin{tabular}{lcccccc}
\hline Kriteria & Bobot & A1 & A2 & A3 & A4 & A5 \\
\hline KKL & $(0,12,0,18,0,27)$ & $(3,5,7)$ & $(5,7,9)$ & $(5,7,9)$ & $(1,3,5)$ & $(5,7,9)$ \\
HT & $(0,12,0,18,0,26)$ & $(5,7,9)$ & $(5,7,9)$ & $(3,5,7)$ & $(3,5,7)$ & $(7,9,9)$ \\
KSBB & $(0,10,0,17,0,24)$ & $(5,7,9)$ & $(7,9,9)$ & $(5,7,9)$ & $(5,7,9)$ & $(3,5,7)$ \\
AST & $(0,07,0,12,0,20)$ & $(7,9,9)$ & $(7,9,9)$ & $(7,9,9)$ & $(7,9,9)$ & $(5,7,9)$ \\
KAL & $(0,06,0,09,0,16)$ & $(7,9,9)$ & $(3,5,7)$ & $(5,7,9)$ & $(7,9,9)$ & $(5,7,9)$ \\
JPK & $(0,05,0,08,0,13)$ & $(3,5,7)$ & $(5,7,9)$ & $(3,5,7)$ & $(7,9,9)$ & $(7,9,9)$ \\
KTK & $(0,05,0,07,0,11)$ & $(3,5,7)$ & $(3,5,7)$ & $(7,9,9)$ & $(5,7,9)$ & $(3,5,7)$ \\
OL & $(0,04,0,06,0,09)$ & $(7,9,9)$ & $(5,7,9)$ & $(7,9,9)$ & $(3,5,7)$ & $(5,7,9)$ \\
ME & $(0,04,0,06,0,09)$ & $(9,9,10)$ & $(5,7,9)$ & $(7,9,9)$ & $(5,7,9)$ & $(7,9,9)$ \\
\hline
\end{tabular}

\section{Tahap 4}

Menggabungkan hasil penilaian pakar ke dalam matriks keputusan fuzzy. Matriks penilaian pakar terhadap setiap alternatif dapat dilihat pada Tabel 10.

\section{Tahap 5}

Menyusun matrik bobot ternormalisasi pada setiap alternatif. Normalisasi nilai dapat dilakukan dengan menggunakan persamaan (5) dan secara detail pada persamaan (6). Matrik hasil normalisasi tersaji pada Tabel 11. 
Tabel 11. Matriks normalisasi skala TFN

\begin{tabular}{lccccc}
\hline Kriteria & A1 & A2 & A3 & A4 & A5 \\
\hline KKL & $(0,33,0,56,0.78)$ & $(0,56,0,78,1,00)$ & $(0,56,0,78,1,00)$ & $(0,11,0,33,0,56)$ & $(0,56,0,78,1,00)$ \\
HT & $(0,56,0,78,1,00)$ & $(0,56,0,78,1,00)$ & $(0,33,0,56,0,78)$ & $(0,33,0,56,0,78)$ & $(0,78,1,00,1,00)$ \\
KSBB & $(0,56,0,78,1,00)$ & $(0,78,1,00,1,00)$ & $(0,56,0,78,1,00)$ & $(0,56,0,78,1,00)$ & $(0,33,0,56,0,78)$ \\
AST & $(0,78,1,00,1,00)$ & $(0,78,1,00,1,00)$ & $(0,78,1,00,1,00)$ & $(0,78,1,00,1,00)$ & $(0,56,0,78,1,00)$ \\
KAL & $(0,78,1,00,1,00)$ & $(0,33,0,56,0,78)$ & $(0,56,0,78,1,00)$ & $(0,78,1,00,1,00)$ & $(0,56,0,78,1,00)$ \\
JPK & $(0,33,0,56,0,78)$ & $(0,56,0,78,1,00)$ & $(0,33,0,56,0,78)$ & $(0,78,1,00,1,00)$ & $(0,78,1,00,1,00)$ \\
KTK & $(0,33,0,56,0,78)$ & $(0,33,0,56,0,78)$ & $(0,78,1,00,1,00)$ & $(0,56,0,78,1,00)$ & $(0,33,0,56,0,78)$ \\
OL & $(0,78,1,00,1,00)$ & $(0,56,0,78,1,00)$ & $(0,78,1,00,1,00)$ & $(0,33,0,56,0,78)$ & $(0,56,0,78,1,00)$ \\
ME & $(0,90,0,90,1,00)$ & $(0,50,0,70,0,90)$ & $(0,70,0,90,0,90)$ & $(0,50,0,70,0,90)$ & $(0,70,0,90,0,90)$ \\
\hline
\end{tabular}

Tabel 12. Matriks perkalian bobot kriteria dan nilai normalisasi alternative

\begin{tabular}{lccccc}
\hline Kriteria & A1 & A2 & A3 & A4 & A5 \\
\hline KKL & $(0,04,0,10,0,21)$ & $(0,07,0,14,0,27)$ & $(0,07,0,14,0,27)$ & $(0,01,0,06,0,15)$ & $(0,07,0,14,0,27$ \\
HT & $(0,07,0,14,0,26)$ & $(0,07,0,14,0,26)$ & $(0,04,0,10,0,20)$ & $(0,04,0,10,0,20)$ & $(0,09,0,18,0,26)$ \\
KSBB & $(0,06,0,13,0,24)$ & $(0,08,0,17,0,24)$ & $(0,06,0,13,0,24)$ & $(0,06,0,13,0,24)$ & $(0,03,0,10,0,19)$ \\
AST & $(0,06,0,12,0,20)$ & $(0,06,0,12,0,20)$ & $(0,06,0,12,0,20)$ & $(0,06,0,12,0,20)$ & $(0,04,0,09,0,20)$ \\
KAL & $(0,04,0,09,0,16)$ & $(0,02,0,05,0,12)$ & $(0,03,0,07,0,16)$ & $(0,04,0,09,0,16)$ & $(0,03,0,07,0,16)$ \\
JPK & $(0,02,0,04,0,10)$ & $(0,03,0,06,0,13)$ & $(0,02,0,04,0,10)$ & $(0,04,0,08,0,13)$ & $(0,04,0,08,0,13)$ \\
KTK & $(0,02,0,04,0,08)$ & $(0,02,0,04,0,08)$ & $(0,04,0,07,0,11)$ & $(0,03,0,05,0,11)$ & $(0,02,0,04,0,08)$ \\
OL & $(0,03,0,06,0,09)$ & $(0,02,0,05,0,09)$ & $(0,03,0,06,0,09)$ & $(0,01,0,03,0,07)$ & $(0,02,0,05,0,09)$ \\
ME & $(0,03,0,05,0,09)$ & $(0,02,0,04,0,08)$ & $(0,03,0,05,0,08)$ & $(0,02,0,04,0,08)$ & $(0,03,0,05,0,08)$ \\
\hline
\end{tabular}

Tabel 13. Nilai solusi ideal positif dan solusi ideal negative

\begin{tabular}{lcl}
\hline Kriteria & \multicolumn{1}{c}{ S* $^{*}$} & $S^{\prime}$ \\
\hline KKL & $(0,27,0,27,0,27)$ & $(0,01,0,01,0,01)$ \\
HT & $(0,04,0,04,0,04)$ & $(0,26,0,26,0,26)$ \\
KSBB & $(0,24,0,24,0,24)$ & $(0,03,0,03,0,03)$ \\
AST & $(0,20,0,20,0,20)$ & $(0,04,0,04,0,04)$ \\
KAL & $(0,16,0,16,0,16)$ & $(0,02,0,02,0,02)$ \\
JPK & $(0,13,0,13,0,13)$ & $(0,02,0,02,0,02)$ \\
KTK & $(0,11,0,11,0,11)$ & $(0,02,0,02,0,02)$ \\
OL & $(0,09,0,09,0,09)$ & $(0,01,0,01,0,01)$ \\
ME & $(0,09,0,09,0,09)$ & $(0,02,0,02,0,02)$ \\
\hline
\end{tabular}

Tabel 14. Nilai jarak antara nilai alternatif dengan FPIS

\begin{tabular}{lccccc}
\hline \multirow{2}{*}{ Kriteria } & \multicolumn{5}{c}{ FPIS $\left(\mathrm{d}^{+}\right)$} \\
\cline { 2 - 6 } & $\mathrm{A} 1$ & $\mathrm{~A} 2$ & $\mathrm{~A} 3$ & $\mathrm{~A} 4$ & $\mathrm{~A}$ \\
\hline KKL & 0,172 & 0,143 & 0,143 & 0,207 & 0,143 \\
HT & 0,142 & 0,142 & 0,101 & 0,101 & 0,155 \\
KSBB & 0,124 & 0,102 & 0,124 & 0,124 & 0,151 \\
AST & 0,094 & 0,094 & 0,094 & 0,094 & 0,110 \\
KAL & 0,078 & 0,105 & 0,090 & 0,078 & 0,090 \\
JPK & 0,084 & 0,071 & 0,084 & 0,061 & 0,061 \\
KTK & 0,069 & 0,069 & 0,048 & 0,057 & 0,069 \\
OL & 0,039 & 0,047 & 0,039 & 0,057 & 0,047 \\
ME & 0,036 & 0,048 & 0,040 & 0,048 & 0,040 \\
\hline d+ & 0,838 & 0,822 & 0,764 & 0,827 & 0,866 \\
\hline
\end{tabular}

\section{Tahap 6}

Menyusun matriks perkalian antara bobot kriteria dengan nilai normalisasi tiap alternatif. Nilai matriks perkalian dapat diperoleh dengan Persamaan (7) dan (8).
Tabel 12 menyajikan matirk hasil perkalian antara bobot kriteria dan nilai normalisasi masing-masing alternatif

\section{Tahap 7}

Menentukan nilai solusi ideal positif (FPIS) $\mathrm{S}^{+}$dan solusi ideal negatif (FNIS) $\mathrm{S}^{-}$. Nilai solusi ideal positif 
Tabel 15. Nilai jarak antara nilai alternatif dengan FNIS

\begin{tabular}{lccccc}
\hline \multirow{2}{*}{ Kriteria } & \multicolumn{1}{c}{ FNIS $\left(\mathrm{d}^{+}\right)$} & & \\
\cline { 2 - 6 } & $\mathrm{A} 1$ & $\mathrm{~A} 2$ & $\mathrm{~A} 3$ & $\mathrm{~A} 4$ & A5 \\
\hline KKL & 0,126 & 0,169 & 0,169 & 0,084 & 0,169 \\
HT & 0,133 & 0,133 & 0,162 & 0,162 & 0,109 \\
KSBB & 0,134 & 0,147 & 0,134 & 0,134 & 0,096 \\
AST & 0,103 & 0,103 & 0,103 & 0,103 & 0,096 \\
KAL & 0,093 & 0,064 & 0,087 & 0,093 & 0,087 \\
JPK & 0,051 & 0,070 & 0,051 & 0,075 & 0,075 \\
KTK & 0,042 & 0,042 & 0,063 & 0,058 & 0,042 \\
OL & 0,053 & 0,049 & 0,053 & 0,035 & 0,049 \\
ME & 0,044 & 0,036 & 0,039 & 0,036 & 0,039 \\
\hline d- & 0,778 & 0,812 & 0,860 & 0,780 & 0,762 \\
\hline
\end{tabular}

merupakan nilai terbaik yang paling memungkinkan untuk dicapai oleh masing-masing kriteria, sedangkan nilai solusi ideal negatif merupakan nilai terburuk yang mungkin dapat terjadi pada masing-masing kriteria. Untuk memperoleh kedua kelompok nilai ideal dilakukan dengan persamaan (9) dan (10). Hasil perhitungan kedua nilai solusi ideal tersaji pada Tabel 13.

\section{Tahap 8}

Menghitung nilai jarak antara masing-masing nilai alternatif dengan nilai solusi ideal positif dan solusi ideal negatif, dilakukan dengan persamaan (11), (12) dan (13). Nilai jarak tiap alternatif dengan kedua nilai solusi ideal, tersaji pada Tabel 14 dan Tabel 15.

\section{Tahap 9}

Hitung nilai koefisien kedekatan (closeness coeficient - CCi ) masing-masing alternatif dengan menggunakan Persamaan (14). Dari hasil yang diperoleh, rangking nilai dari yang terbesar hingga terkecil dimana nilai koefisien terbesar merupakan alternatif terpilih. Hasil perhitungan nilai koefisien kedekatan untuk masing-masing alternatif tersaji pada Tabel 16.

Tabel 16. Koefisien kedekatan dan rangking alternative

\begin{tabular}{ccc}
\hline Lokasi & Cci & Rangking \\
\hline A1 & 0,48 & 4 \\
A2 & 0,50 & 2 \\
A3 & 0,53 & 1 \\
A4 & 0,49 & 3 \\
A5 & 0,47 & 5 \\
\hline
\end{tabular}

Berdasarkan perhitungan nilai koefisien kedekatan tersebut, maka dapat dilihat bahwa alternatif lokasi A3 memiliki nilai koefisien terbesar di bandingkan dengan alternatif lokasi lainnya. Oleh karenanya, rekomendasi keputusan dalam penentuan lokasi adalah pada alternatif lokasi ke-3.

\section{KESIMPULAN}

Pada penelitian ini telah dibangun suatu model keputusan dalam menentukan lokasi kawasan yang menjadi sasaran pengembangan bioenergi. Melalui analisis perbandingan, telah diketahui bahwa kriteria terpenting dalam penentuan lokasi suatu kawasan pengembangan agroindustri bioenergi adalah faktor ketersediaan dan kondisi lahan (KKL). Berdasarkan analisis dengan menggunakan metode Fuzzy TOPSIS, dari lima alternatif lokasi yang di nilai menurut pereferensi pakar, telah terpilih wilayah Pelintung Dumai, sebagai lokasi paling ideal dengan nilai koefisien kedekatan tertinggi sebesar 0,53.

\section{DAFTAR PUSTAKA}

Badan Pengkajian dan Penerapan Teknologi (BPPT). (2011). Mapping Potensi dan Penyediaan Bahan Baku Bioenergi Nasional. Indo Bioenergy 2011. Jakarta.

Christou, I. T. (2012). Quantitative Method in Supply Chain Management, Model and Algorithm. Springer London Dordrecht Heidelberg New York.

Chapman, K. (2009). Industrial Location. Elsevier.

Dewanti, A. N. \& Santoso, E.B. (2012). Penentuan alternatif lokasi pengembangan kawasan agroindustri berbasis komoditas pertanian unggulan di Kabupaten Lamongan. Jurnal Teknik Institut Teknologi Surabaya, 1, 33-37. Doi: 10.12962/j23373539.v1i1.925.

Dinas Perkebunan Provinsi Riau (2012). Statistik Perkebunan Provinsi Riau Tahun 2012. Pekanbaru, Riau.

Direktorat Energi Baru, Terbarukan dan Konservasi Energi, Kementrian Energi danSumber Daya Mineral (EBTKEKESDM). (2011) Kebijakan Pengembangan Bioenergi. Materi Workshop Penyusunan Kebijakan Bioenergi. Pekanbaru, Riau

Energy Research Center (Enreach) (2013). Potensi Energi Biomassa di Provinsi Riau. Buku Laporan Proyek Setting Up a Renewable Energy Clearing House in Riau Province Project Financed by Ministry for Foreign Affair of Finland.

Gunarta, I. K. (2013). Pengembangan industri crude palm oil berkelanjutan dengan menggunakan model geo-spatial multicriteria decision analysis. Jurnal Bumi Lestari, 13(1), 16-26.

Hambali, E. Thahar, A., \& Komarudin, A. (2010). The potential of oil palm and rice biomass as bioenergy feedstock. Th Biomass Asia Workshop, November 29 - December 01, 2010, Jakarta, Indonesia.

Hwang, C. L. \& Yoon, K. (1995). Multiple Attributes Decision Making Methods and Application. An Intorduction. Sage 
Publications. International Educational and Profesional Publisher. Thousand Oak. London. New Delhi.

Joni, R. (2010). Dampak pengembangan industri biodiesel dari kelapa sawit terhadap perkebunan kelapa sawit dan industri minyak kelapa sawit di Indonesia. Jurnal Teknologi Industri Pertanian, 20(3), 143-151.

Kementerian Perindustrian Republik Indonesia (2010). Peraturan Menteri Perindustrian Republik Indonesia No. 35 Tahun 2010, Tentang Pedoman Teknis Kawasan Industri.

Kusumadewi (2003). Artificial Intelligence: Teknik dan Aplikasinya. Yogyakarta: Graha IImu.

Laila, F. N. \& Santoso, E. B. (2014). Penentuan kawasan agroindustri berbasis komoditas unggulan sektor pertanian di Kabupaten Probolinggo. Jurnal Teknik Pomits, 3(2), 142147.

Ningrum, M. Sutarman, \& Sitepu. (2012). Aplikasi metode topsis fuzzy dalam menentukan prioritas kawasan perumahan di kecamatan percut sei tuan. Jurnal Saintia Matematika, 1(1), 101-115.

Rouyendegh \& Saputro (2014). Supplier selection using integrated fuzzy topsis and MCGP: a case study. Procedia Social and Behavioral Sciences, 116, 3957-3970.

Soerawidjaja, T. H. (2011). Rintangan-rintangan percepatan implementasi bioenergi. Makalah Seminar KADIN "Memasuki Era Energi Baru dan Terbarukan untuk Kedaulatan Energi Nasional' Jakarta Convention Center 14 Juli 2011.

Uyun, S. \& Riadi, I. (2011). A fuzzy topsis multplei-attribute decision making for sholarship selection. Jurnal Telkomnika, 9(1), 37-46.

Wardani, I. K., Usadha, I. G. N. R., \& Irawan, M. I. (2012). Seleksi supplier bahan baku dengan metode fuzzy topsis MADM (studi kasus PT. Giri Sekar Sedaton, Gersik). Jurnal Sains dan Seni POMITS, 1(1), 1-6 